The scheme of technological process of service enterprise is made according to which the car is first directed to the site of acceptance for repair, and then to any of the production areas of the car service (areas of diagnosis, maintenance, repair and repair stations). The choice of low-quality service (work) of the surveyed production area (site) is carried out according to the normalized ranking of importance, taking about the specific weight of orders. The analysis of production activity of the service enterprise is carried out in which at different stages the dispatcher, the master - the receiver, the foreman, the engineer of engineering and technical service take part. The graphical interpretation of the services quality at the engine diagnostics department based on the generalized customer questionnaire data and data on the production activity of the station is given. To improve the quality of maintenance work on fuel systems is the technological equipment of the workplace in accordance with the typical requirements and bringing in the necessary technical condition of the main technological equipment.

service enterprise, production capacity, regular customers, services quality

Одержано (Received) 17.04.2020

Прорецензовано (Reviewed) 29.04.2020

Прийнято до друку (Approved) 19.10.2020

УДК 656.13

DOI: https://doi.org/10.32515/2664-262X.2020.3(34).369-376

Vladyslav Ershov, post-graduete, Serhiy Nedilko, Prof., DSc., Oleksiy Izvalov, Vitaliy Nedilko, Assoc. Prof., PhD tech. sci.

Flight Academy of National Aviation University, Kropivnitsky, Ukraine

\title{
Safety Of Drones Flows In Conditions Of Their Mass Use In The City
}

In the sphere of entertainment, drones have become much more accessible over the past two years and have received a set of serious instruments - cameras, autopilots, etc. Their cost became acceptable, the functionality grew, management became easier.

All over the world, rules are being developed and implemented for the use of unmanned aerial vehicles to regulate flights and eliminate potential dangers.

Actual is the analysis of the legislative framework for the flight of drones of various countries, as well as the development of the concept of safe flight of a large number of drones in the urban environment.

drones, mass use, safety of flows, UASes, GPS, law regulations, BAPLA, SACAA, RPA, unmanned aerial vehicles, IoT, CAA, SAAU

В.В. Ершов, асп., С.Н. Неделько, проф., д-р техн. наук, А.В. Извалов, В.Н. Неделько, доц., канд. техн. наук Лётная академия Национального авиаџионного университета, г. Кропивницький, Украина

Безопасность потоков дронов в условиях их массового использования в городской среде

В сфере развлечений и целевого использования беспилотники стали намного доступнее за последние два года и получили набор серьезных инструментов - камеры, автопилоты и т. д. Их стоимость стала приемлемой, функциональность выросла, управление стало проще.

Во всем мире разрабатываются и применяются правила использования беспилотных летательных аппаратов для регулирования полетов и устранения потенциальных опасностей.

Актуальным является анализ законодательной базы для полетов дронов разных стран, а также разработка концепции безопасного полета большого количества беспилотников в городской среде.

беспилотные летательные аппараты, массовое использование, безопасность потоков, GPS, правовые нормы, ВАРLA, БПЛА, беспилотные летательные аппараты, IоТ

(C) Vladyslav Ershov, Serhiy Nedilko, Oleksiy Izvalov, Vitaliy Nedilko, 2020 
Statement of the problem.. Drone - in the technological context, it's an unmanned aerial vehicle. Formally, drones are known as unmanned aerial vehicles (UAVs) or unmanned aerial systems (UASes). Essentially an unmanned flying robot.

UAVs can be remotely controlled, and can fly autonomously with th0,e built-in software (flight plan), working in close connection with on-board sensors and GPS systems.

In the recent past, unmanned aerial vehicles had exclusively military applications, where they were originally used to destroy aerial targets and collect intelligence information.

Now the drones have been widely used, ranging from search and rescue operations, sur-veillance, weather monitoring, traffic, fire extinguishing, for personal purposes, business with an emphasis on photo and video shooting, in agriculture and even in cargo delivery services.

The main material. The first unmanned aerial vehicle was realized in 1935 using the example of the full-size biplane De Havilland DH82B "Queen Bee". It was equipped with a radio receiver and control servo located in the rear seat. Later it was used as a live target for training firing from anti-aircraft installations with the goal of training artillerymen. In total, 380 De Havilland DH82B "Queen Bee" aircraft were built. The term "drone" was born thanks to this historic event.

At the end of 2012, Chris Anderson, resigned from the post of editor-in-chief of the maga-zine "Wired" in order to lighten himself with drones in the company 3DRobotics Inc. Later, within the walls of this company, the unique code of the universal flight APM was first written, on the basis of which the famous high-class autopilot Pixhawk was realized. At the moment the company specializes in UAV and realizes its advanced solutions in such areas as photo and video shooting, construction, utilities, telecommunications services, as well as in ensuring public safety.

In late 2013, the well-known public company Amazon was one of the first to use commer-cial drones to deliver the products sold. Later in 2016, this idea was supported by: the Poly-technic University of Virginia and the State Institute in conjunction with the Alphabet Inc hold-ing company, using the example of the test project "Wing", whose goal was to deliver goods purchased on the Internet or essentials with the help of drones.

From BI Intelligence report "The drones Report": "The profit from the implementation of drones will increase to $\$ 12$ billion by 2021 [1]. Analysts at BI Intelligence estimated that in 2015 it already amounted to more than $\$ 8000000000$.

Embry-Riddle - Aviation University, for a long time was a training ground for the aviation industry. Currently, he offers a Bachelor of Science in unmanned systems, a Master of Science degree in unmanned systems, and also conducts basic training courses in the field of unmanned aerial systems.

The integration of unmanned aerial vehicles and the Internet has made it possible to use drones everywhere in enterprises. Drones operate on IoT terrestrial sensor networks, help agri-cultural companies monitor lands and crops, energy companies use drones to inspect power lines and related equipment.

Law regulations of the drones flows in the world. Drones have long been more widely used than use in law enforcement and specialized-commercial spheres. Now they can be seen in private hands.

In the sphere of entertainment, drones have become much more accessible over the past two years and have received a set of serious instruments - cameras, autopilots, etc. Their cost became acceptable, the functionality grew, management became easier.

All over the world, rules are being developed and implemented for the use of unmanned aerial vehicles to regulate flights and eliminate potential hazards, which, 
unfortunately, are not uncommon. For example, an unidentified drone was close to a collision with the A320 Airbus during a landing in London's Heathrow in the summer of 2014 [2].

A. Russia

Since the beginning of April 2016 in Russia there is a mandatory registration of UAVs weighing more than 250 grams, including toy drones. They will be registered by the Federal Security Service. The relevant decree was adopted and signed on 30.12.15 [3].

Owners of unmanned vehicles, both acquired in Russia, and imported to the territory of the Russian Federation from abroad, will be required to register them in the controlling body. The management department will need to provide information on the country of manufacture of the drone, its serial number, the year of manufacture, the purpose of the device, its maximum take-off mass, as well as the type, number and power of its engines.

In addition, UAV owners will need to report to the FSS the name of the owner (or the name of the organization that owns the drone), the date and place of birth of the person, as well as his passport and contact information.

\section{B. European Union}

Despite the fact that the European Union is one of the leaders in the production and use of drones, there are currently no laws that establish clear rules for flights.

At the end of 2015, the European Parliament adopted a resolution that focuses the Europe-an Commission's attention not only on security but also on the inviolability of private life affect-ed by the use of unmanned aerial vehicles that are capable of collecting and storing photo or video images [4].

The resolution also calls for equipping drones with unique chips, identifying the identity and registration data of the pilot.

\section{Ireland}

In some countries there are local regulations, for example, in Ireland from 21.12.15 all drones over $1 \mathrm{~kg}$ should be registered with the IAA. Ireland has taken an active role in the fast-growing region and is one of the few EU member states involved in drafting legislation regulat-ing the use of unmanned aerial vehicles.

D. Italy

In Italy, there is a ban on the use of quadrocopters (for non-commercial shooting, lighter than $25 \mathrm{~kg}$ ) with a large crowd of people, in cities, near railway stations, airports, military instal-lations, power stations and government agencies.

It is allowed to launch drones in an open, well-viewed space at a distance of not less than 150 meters from the city infrastructure, while maintaining constant visual contact with the appa-ratus. Pilot can not approach more than 50 meters to people and objects of private property. Shooting is prohibited within a radius of $8 \mathrm{~km}$ from the airport. For commercial shooting, pilot need to buy a license.

E. Austria

In Austria, the zones allowed for flights are divided into 4 categories. Without a license, pilot can fly only in open spaces (in nature) and near farmlands (farms).

F. Czech Republic

In the Czech Republic, drones are banned in cities and in crowded places. Unmanned ve-hicles weighing less than $7 \mathrm{~kg}$ are allowed to run at a safe distance from people and buildings, vehicles weighing 7 to $20 \mathrm{~kg}$ should fly at a distance of not less than 150 meters from people and buildings.

G. United Kingdom

The Civil Aviation Authority (CAA) establishes rules for flights on drones, which is called the air navigation order. 
There are conditions under which a drone weighing less than $20 \mathrm{~kg}$. does not require sepa-rate registration and licensing:

- $\quad$ Drone must be used within the "line of sight". Parameters of the zone: air space in the perimeter of 500 meters $(1,640 \mathrm{ft})$ horizontally or 400 feet $(122 \mathrm{~m})$ vertically;

- $\quad$ An unmanned aircraft equipped with a photo camera should be located at a distance of not less than $50 \mathrm{~m}$ (164ft) from a person, car, building or any structure;

- Copter for private purposes can not be used in the zone of a large group of people, such as a sporting event or a concert (no closer than $150 \mathrm{~m}$ );

- $\quad$ For commercial purposes, operators must have permission to fly drones from CAA

The British Pilot Association (BALPA) defends the need for programming drones for auto-restraint of airspace for flight operations. It's about installing a kind of geo-block. Some com-mercial series already includes a geo-lock.

GPS-tracker contains coordinates of thousands of airports around the world. It does not al-low entering these areas. If the copter approaches the boundary of the blocked zone (within a radius of $2 \mathrm{~km}$ from a large airport), in automatic mode its flight altitude will be limited to $10 \mathrm{~m}$.

H. Canada

In Canada, the regulation and control of flights on drones is carried out by the Ministry of Transport of Canada.

To assess the need to obtain a special permission to fly flights, we can use special graphical scheme prepared by the Ministry of Transport of Canada.

Briefly, special permission is not required in case of the following conditions:

- Pilots are not going to use Copter for research and commercial purposes.

- Flight device weighing less than $25 \mathrm{~kg}$.

- Pilots follow the standard flight safety rules (do not threaten anyone or anything).

I. United States of America

According to the newest rules, those pilots who purchased drones before December 21, 2015, will be required to register them in the database before February 19, 2016. The remain-ing UAV owners will need to register drones before their first flight. Registration is carried out on the FAA website, cost is $\$ 5$. For refusal of registration, a fine of $\$ 27000$ is threatened.

The regulatory law was adopted not so long ago, but by now more than $300000 \mathrm{UAV}$ owners have registered in the US.

In addition, the Federal Aviation Administration (FAA) prohibits the flight of unmanned aircraft, including hobby drones, above 122 meters.

Similarly, in the event that drones are used at a distance of 5 miles from the airport, control-lers must be notified in advance of its air traffic pattern.

Pilots can not use copters in the Yosemite National Park, so as not to disturb the birds and animals (this is the rule in many nature reserves of the world).

At the same time, each state has its own rules that allow or prohibit drones. The drone should not weigh more than $25 \mathrm{~kg}$.

J. South Africa

Without the need for a license, regulation presupposes that:

- use of drones does not involve commercial interest;

- the range of flight is not more than 500 meters from the pilot's location and in the distance more than 50 meters from buildings and public routes; 
- the presence of a first aid kit and a fire extinguisher within $300 \mathrm{~m}$ from the runway;

- taking into account traffic, unmanned aerial vehicles should always give way to manned aircraft.

For commercial purposes, drones necessarily require licensing (RPA) and registration with the Civil Aviation Administration of South Africa (SACAA). Acquisition of the license requires medical examination, knowledge of the English language, passing training courses for flights, ending with a theoretical examination and a test of practical skills.

The license is valid for 24 months and can be issued to individuals who have reached the age of 18 years. The license holder will also have to pass the re-certification 90 days prior to the expiry of its validity term for renewal. The RPA license can be issued in three categories: air-craft, helicopter or multi-rotor.

In accordance with the new laws, RPA pilots will also be required to maintain a pilot $\log$ with a detailed description of each flight carried out. acronyms.

K. Morocco

In Morocco, the survey is allowed, but only by the apparatus that was purchased in the country.

L. Australia

All flights operated for commercial purposes must be registered.

If the drone weighs less than $2 \mathrm{~kg}$ and flights are carried out for private purposes (hobby / entertainment), additional registration is not required, but there is a list of mandatory conditions requiring compliance:

- A pilot can not fly closer than $30 \mathrm{~m}$ from vehicles, boats, buildings that are not located on the private property or a pilot does not own a permit from the owner of a private property.

- A pilot can not fly over populated areas and over crowded areas such as public beaches, foreign yards / parks, parks and public recreation areas, sporting events and play areas.

- A pilot can not work within a radius of $5.5 \mathrm{~km}$ from any aerodrome, airport, in the take-off and landing areas of helicopters that can be located in hospitals, police stations and other places that are not obvious on first examination. It is the responsibility of the pilot, before planning the flight, it is necessary to take into account the location data (ignorance does not absolve from responsibility).

- Flights are allowed only during the daytime. Only in good weather and within the visibility of the pilot.

- The range should not exceed 400 feet (123 meters).

M. Thailand

In Thailand, the launch of drones equipped with cameras is prohibited. This is due to the lack of an approved procedure for the use of UAVs.

At the moment, the Ministry of Transport of Thailand is developing a bill, which will fix in-struments to regulate privacy issues.

Law regulations of the drones flows in Ukraine. The State Aviation Administration of Ukraine (SAAU) has developed a "Concept for regulating the direction of unmanned aircraft" [7]. The similar rules - FAR-107 - have already been operating in the US since August 2016, European regulator European Aviation Safety Agency (EASA) published a draft of its document on market regulation.

The SAAU document provides for 2 types of classification of unmanned aerial vehicles: the maximum take-off mass and the types of control. 
According to the first criterion, there are four categories of aircraft (aircraft):

1. to $0.250 \mathrm{~kg}$;

2. $0.25-20 \mathrm{~kg}$;

3. $20-150 \mathrm{~kg}$;

4. more than $150 \mathrm{~kg}$.

By the second criterion there is a manual visual, manual instrumental and stand-alone appa-ratus.

In addition, it is expected that they will distinguish between commercial and noncommercial exploitation.

Depending on the class of aircraft, different requirements are imposed on its owners. The largest - the same as for manned aircraft, and when using the smallest - it is enough to follow the rules of aviation security.

In this case, certain requirements can be introduced to operators of drones.

Owners of Class 1 aircraft (from 0.25 to $20 \mathrm{~kg}$ ) can operate them only in conditions of direct visual contact without additional devices. The maximum speed should not exceed 150 $\mathrm{km} / \mathrm{h}$ with a maximum flight altitude of up to $120 \mathrm{~m}$ and a radius of $500 \mathrm{~m}$. The ban on flights in the 8-kilometer zone from the perimeter of the airport, as well as restricted areas is prohibited. Use an unmanned aerial vehicle (UAV) of this class can only be in the daytime.

Also definitions of the remote pilot and the visual observer are introduced. The first of them is a person who manipulates the controls of an unmanned aircraft during the flight and has the right to a final decision, and is also responsible for the safety of the UAV during flights. The second one - visually observes the aircraft and provides information about the parameters of its flight to the remote pilot.

For second-class vehicles $(20-150 \mathrm{~kg})$, mandatory certification is required in the State Avia-tion Service, certification of the type / flightability requirements and obtaining an operator's certificate.

All UAV flights should not be performed on people other than a remote pilot or visual ob-server. The remote pilot can at the same time manipulate only one drone. When using the drone, a remote pilot should be preflighted. On drones there should be no hazardous materials, except for food items.

The remote pilot must ensure a normal physical and psychological condition for safe opera-tion (alcohol consumption or fatigue).

The State Aviation Administration of Ukraine intends to introduce new amendments to the Air Code of Ukraine, engage in discussion and improvement of the project of the Aviation Regulations of Ukraine, develop and launch an online educational course for users and a web-site with rules for the safe operation of UAVs.

Also the State Aviation Administration of Ukraine is on the way to develop a training course for obtaining a certificate of a remote pilot of such aircraft.

Automatic calculation of the safety of drones flows in urban conditions. At a result of analysis of the given regulations, the need to automatize the safety assessment of UAV routes emerges. Such automatization can be achieved by adapting the model of air traffic flows, used in [8] for exercise design in air traffic control simulators. Performance differ-ences between aircraft and UAV are taken into account, as well as difference scales of air traffic service area and a single city. At the moment, the development of software, which incorporates these models and allows to consider the law regulations of drone flows on the actual area and calculate the safest routes for the drones according to these regulations, is in progress. 
The software contains the map of the current urban area with the common drone flight routes, shown as black lines. The places of potential unsafe zones are shown as red circles. The software detects these zones and optimizes the routes to avoid collisions between the drones.

The software can be run on mobile and web. The possible fields of application of this soft-ware can include safety calculation for new UAV routes opening, assessment of implementa-tion of the new generation of UAV, individual routes planning.

Conclusion. The huge demand for commercial and private drones also caused a number of problems related to safety, regarding the consequences of collisions and loss of control. In this regard, many countries at the legislative level have introduced a number of amendments to the air code. The "No-fly" zones appeared.

As a result of variety of law regulations, there is a need create the automatic system for calcu-lation of the safety of drones flows in urban conditions and for prediction of the approximated safest routes of the flow.

\section{Список літератури}

1. IHS Jane`s Intelligence Review, 2015; Intelligence Estimates, 2016 (references).

2. The UK Airprox Board Report from 7 Dec 2014, pp. 8-13.

3. Federal Law No. 462-FZ of 30.12.2015 "On Amending the Air Code of the Russian Federation with regard to the Use of Unmanned Aircraft", pp. 1-5.

4. Drones: guidelines for rules on commercial and recreational use and safety Resolution, EU Press Release, Ref.: 20151022IPR98819, 29-10-2015.

5. Regulation on common rules in the field of civil aviation and establishing a European Union Aviation Safety Agency (EC) No 216/2008 of the European Parliament, pp. 14-65.

6. Использование авиамоделей в Республике Беларусь. Совет Министров Республики Беларусь; Постановление, Правила от $16.08 .2016 \quad$ № $636 . \quad$ URL: http:/government.by/upload/docs/fileaeab4fba05047ee0.PDF (дата обращения: 17.03.2020).

7. Про затвердження Правил польотів повітряних суден та обслуговування повітряного руху в класифікованому [...] . Мінтранс України; Наказ, Правила від 16.04.2003 № 293 . URL: http://zakon3.rada.gov.ua/laws/show/z0346-03 (дата обращения: 17.03.2020).

8. Aleksey Izvalov, Sergey Nedelko, Vitaliy Nedelko. Set of Software for Automatic Control System of the Air Traffic Modeling Complex. Техніка в сільськогосподарському виробництві, галузеве машинобудування, автоматизація: зб. наук. пр. Кіровогр. наи. техн. ун-ту. 2014. Вип. 27. С. 266274. URL: http://nbuv.gov.ua/UJRN/znpkntu_2014_27_41 (дата обращения: 20.03.2020).

\section{References}

1. IHS Jane`s Intelligence Review, 2015; Intelligence Estimates, 2016 (references) [in English].

2. The UK Airprox Board Report from 7 Dec 2014, pp. 8-13 [in English].

3. Federal Law No. 462-FZ of 30.12.2015 "On Amending the Air Code of the Russian Federation with regard to the Use of Unmanned Aircraft", pp. 1-5 [in English].

4. Drones: guidelines for rules on commercial and recreational use and safety Resolution, EU Press Release, Ref.: 20151022IPR98819, 29-10-2015 [in English].

5. Regulation on common rules in the field of civil aviation and establishing a European Union Aviation Safety Agency (EC) No 216/2008 of the European Parliament, pp. 14-65 [in English].

6. Ispol'zovanie aviamodelej v Respublike Belarus'. Sovet Ministrov Respubliki Belarus'; Postanovlenie, Pravila ot 16.08.2016 № 636. [Use of aircraft models in the Republic of Belarus. Council of Ministers of the Republic of Belarus; Resolution, Rules of 16.08.2016 N 636.]. government.by. Retrieved from http://government.by/upload/docs/fileaeab4fba05047ee0.PDF [in Russian].

7. Pro zatverdzhennia Pravyl pol'otiv povitrianykh suden ta obsluhovuvannia povitrianoho rukhu v klasyfikovanomu [...] . Mintrans Ukrainy; Nakaz, Pravyla vid 16.04.2003 № 293 [About approval of the Rules of Aircraft Flight and Air Traffic Services in the classified [...] ]. Ministry of Transport of Ukraine; 
Order, Rules of 16.04.2003 N 293. zakon3.rada.gov.ua. Retrieved from http://zakon3.rada.gov.ua/laws/show/z0346-03 [in Ukrainian].

8. Aleksey Izvalov, Sergey Nedelko \& Vitaliy Nedelko (2014). Set of Software for Automatic Control System of the Air Traffic Modeling Complex, 27, 266-274. Retrieved from http://nbuv.gov.ua/UJRN/znpkntu_2014_27_41 [in English].

В.В. Сршов, асп., С.М. Неділько, проф., д-р техн. наук, О.В. Ізвалов, В.М. Неділько, доц., канд. техн. наук

Льотна академія Національного авіаџійного університету, м. Кропивницьький, Украӥна

\section{Безпека потоків дронів в умовах їх масового використання в міському середовищі}

У сфері розваг і цільового призначення за останні два роки безпілотники стали набагато доступнішими і отримали набір серйозних інструментів - камери, автопілоти тощо. Їх вартість стала прийнятною, функціональність зростала, управління стало простішим.У всьому світі розробляються та впроваджуються правила щодо використання безпілотних літальних апаратів для регулювання польотів та усунення потенційних небезпек.Актуальним $є$ аналіз законодавчої бази щодо польоту безпілотників різних країн, а також розробка концепції безпечного польоту великої кількості безпілотників у міському середовищі.

сервісні безпілотники, масове використання, безпека потоків, GPS, нормативно-правові акти, БАПЛА, БПЛА, безпілотники, ІоТ 